\title{
Mediasi Penal sebagai Alternatif Upaya Penyelesaian Perkara Pidana di Luar Pengadilan
}

\section{Teguh Hariyono}

Magister Hukum, Universitas Muhammadiyah Yogyakarta, Indonesia

Corresponding Email: teguh.haryono.pasca17@mail.umy.ac.id

\begin{tabular}{l} 
INFO ARTIKEL \\
\hline Perjalanan Artikel: \\
Artikel Dikirimkan oleh \\
penulis: 01-05-20 \\
Artikel Direview: $23-07-20$ \\
Artikel Direvisi: 09-03-21 \\
Artikel Diterima atau \\
Dipublikasikan: 27-04-21 \\
DOI: \\
https://doi.org/10.18196/jphk \\
.v2i1.8731 \\
\end{tabular}

\begin{abstract}
ABSTRAK
Penanganan masalah non-pidana dengan menggunakan mediasi hukuman belum memiliki dasar hukum, tetapi fenomena mediasi pidana sudah banyak digunakan dalam proses penyelesaian kasus pidana. Penelitian ini bertujuan untuk menguji keberadaan mediasi pidana dalam menangani tindak pidana dan relevansi mediasi pidana dengan upaya untuk mewujudkan keadilan restoratif dalam menangani tindak pidana. Pada penelitian digunakan model studi kepustakaan dengan pendekatan normatif. Hasil penelitian menunjukkan terkait dengan keberadaan mediasi filosofis dan sosiologi hukuman telah menjadi bagian dari masyarakat Indonesia. Secara yuridis, mediasi penal dalam kasus pidana belum memiliki dasar hukum yang kuat meskipun dalam praktiknya hukuman tersebut sering dilakukan di masyarakat. Momentum tentang penggunaan mediasi dalam menyelesaikan kasus pidana setelah dikeluarkannya Surat Kepolisian yang membahas Alternatif Penyelesaian Sengketa. Mediasi pidana juga mendorong upaya untuk menciptakan keadilan restoratif, yang mengedepankan upaya pemulihan karena musyawarah untuk mencapai konsensus.
\end{abstract}

Kata Kunci : mediasi pidana, keadilan restoratif, sistem penegakan hukum pidana

\section{Pendahuluan}

Pelaksanaan hukum dalam kehidupan masyarakat memiliki makna yang penting dalam menciptakan keadilan, kepastian dan manfaat bagi masyarakat. Hukum yang berjalan sesuai dengan ketentuan dan diikuti oleh setiap masyarakat mampu menciptakan keadilan. Hukum harus dilaksanakan dan dipatuhi oleh setiap individu, dan setiap individu harus diperlakukan sama di depan hukum. Apabila hukum dipatuhi oleh setiap individu, maka hukum memberikan rasa keadilan, kepastian dan manfaat yang baik bagi masyarakat.

Hukum secara umum terbagi dalam dua kategori, yaitu hukum publik dan privat, meskipun dalam beberapa situasi hukum, ada yang mengandung kedua unsur antara hukum publik dan privat sekaligus. Perbedaan antara hukum publik dan privat terletak pada titik berat apakah individu atau sekumpulan manusia. Apabila titik berat pada satu orang manusia maka dalam penetapan terkait bagaimana hukum 
diimplementasikan secara langsung diserahkan kepada individunya. Apabila titik beratnya pada kumpulan manusia, maka untuk menetapkan hukum dilaksanakan diserahkan pada kumpulan manusia tadi. Hukum publik sendiri masuk menjadi bagian dalam kategori hukum pidana, sedangkan hukum privat masuk menjadi bagian kategori hukum perdata. ${ }^{1}$

Hukum pidana dan perdata dalam beberapa kasus dalam hubungan bisnis dapat terjadi bersama. Terkait dengan hubungan bisnis yang berlangsung dapat dijelaskan sebagai hubungan privat, tetapi di lain sisi apabila dikaji lebih dalam, hubungan bisnis juga memiliki keterkaitan dengan permasalahan hukum publik yang masuk dalam kategori hukum pidana. Salah satu contohnya, ketika terjadi kasus penipuan dalam pembuatan perjanjian bisnis, maka tindak pidana penipuan termasuk dalam kategori hukum pidana. Pada kasus lain keterkaitan antara satu pihak dan pihak lain dalam perjanjian bisnis masuk dalam kategori hukum perdata.

Permasalahan pidana dan perdata memang dapat terjadi dalam kasus yang sama, namun hukum pidana memiliki perbedaan yang sangat mendasar dengan permasalahan hukum perdata. Perbedaannya dalam hukum pidana mengatur permasalahan yang muncul agar proses penyelesaiannya dilakukan oleh lembaga peradilan negara. Proses penyelesaian masalah tindak pidana menurut teori hukum memiliki cara-cara tertentu yang di atur dalam hukum acara pidana. Hukum acara pidana mengatur terkait dengan proses penyerahan laporan, masalah seperti apa yang harus dilaporkan, dan ada pula yang harus diadukan. Untuk menyelesaikan permasalahan terkait hukum pidana, masing-masing negara mempunyai instansi yang digunakan sebagai lembaga yang menjaga dan mengatur hukum pidana agar mencapai peradilan yang diharapkan. Adapun instansi yang menangani terkait masalah pidana disebut aparat penegak hukum, yang memiliki tugas dan fungsi dalam penyelesaian masalah pidana. ${ }^{2}$

Fenomena yang berkembang saat ini yaitu semakin banyak usaha penyelesaian perkara pidana dengan cara non litigasi atau dengan upaya damai. Upaya damai sering dilakukan juga dalam masalah pidana di dunia bisnis, manakala terjadi kasus pidana maka pihak terkait cenderung mengambil jalur perdamaian karena dianggap efektif dan efisien dibandingkan melalui proses peradilan yang menyita waktu dan tenaga. Upaya perdamaian untuk perkara pidana masih merupakan suatu hal yang dipertanyakan, karena menurut Nelly Pinangkaan terdapat ketentuan bahwa "tak ada perdamaian dalam pidana" dan "tercapainya perdamaian, tidak menghilangkan unsur pidana yang ada". Berbeda dengan perkara perdata, dimana upaya damai merupakan hal yang sudah terlegitimasi dengan asas dan peraturan-peraturan yang terkait dengan keperdataan. ${ }^{3}$

1 Projodikoro, W. (2003). Asas-Asas Hukum Pidana di Indonesia, Jakarta: Refika Aditama, hal. 2.

2 Reyner (2018). Alternatif Mediasi Penal Dalam Sistem Peradilan Pidana di Indonesia. Jurnal Hukum Adigama, 5(1). 1 - 26, hal. 2.

3 Pinangkaan, N. (2017). Penerapan Mediasi Penal Dalam Penanganan Tidak Pidana Dalam Pendekatan Keadilan Restoratif Di Kota Manado. Lex Et Societatis, 5(8), 175-188, hal. 3. 
Praktik mediasi penal yang marak dilakukan saat ini oleh penegak hukum memberikan gambaran bahwa terjadi pergeseran dari retributive justice kepada restorative justice. Hal ini tentu memerlukan pengaturan yang lebih baik, sehingga proses dan tahapan mediasi penal oleh penegak hukum dalam penanganan pidana memberikan rasa keadilan dan seimbang. ${ }^{4}$ Ini juga diperlukan supaya tidak ada pihak yang mengambil keuntungan dari adanya mediasi penal. Sebagai contoh, untuk menyelesaikan suatu kasus tertentu agar tidak masuk dalam pengadilan dan dengan cara pengadilan tetapi ada pihak penegak yang memanfaatkan mediasi penal untuk menyelesaikan sengketa, tetapi dengan merugikan salah satu pihak tertentu.

Perkembangan secara teoritis dan pembaharuan hukum pidana di beberapa negara, ada kecenderungan kuat untuk menggunakan mediasi penal sebagai suatu alternatif penyelesaian masalah dalam bidang hukum pidana. Mediasi penal merupakan salah satu bentuk dari penerapan keadilan restoratif yang berorientasi kepada korban. Mediasi penal merupakan proses menyelesaikan suatu perkara pidana yang terjadi dengan cara mempertemukan pelaku dan korban tindak pidana dengan tujuan menyelesaikan sengketa yang terjadi tanpa masuk jalur litigasi. Litigasi atau gugatan merupakan tindakan suatu pihak yang memiliki masalah hukum dan dilaporkan ke pengadilan hukum. Menurut Prof. Detlev Frehsee, pertemuan antara korban dan pelaku sudah menggeser pandangan terkait penyelesaian hukum pidana yang memiliki filosofi positivistik ke pandangan yang lebih bersifat humanistis.

Penyelesaian sengketa alternatif adalah menyelesaikan sengketa yang berada di luar pengadilan, yang dilakukan sah menurut hukum yang didasarkan konsensus dari pihak terkait. ${ }^{5}$ Soerjono Soekanto menyatakan bahwa inti pengertian law enforcement ialah bertitik fokus untuk menyelaraskan keterkaitan nilai-nilai yang diuraikan dalam kaidah-kaidah yang dan menjabarkan sikap tindak sebagai rangkuman pengejawantahan pada nilai tahap akhir, guna menciptakan, memelihara serta mempertahankan kedamaian dalam kehidupan sosial. ${ }^{6}$

Masyarakat sudah sejak lama mengetahui dan mengikuti sistem yang dijadikan pedoman untuk berperilaku dalam masyarakat. Pada beberapa kasus, apabila suatu pihak melakukan pelanggaran pada pedoman yang berperilaku dalam masyarakat sebagai contoh pencurian suatu barang, melakukan kekerasan, penipuan dan lain-lain maka masyarakat biasanya akan melaporkan ke penegak hukum setempat seperti polisi. Pihak yang bersalah kemudian diperiksa, apabila di persidangan terbukti bersalah selanjutnya akan mendapatkan hukuman. Disisi lain masyarakat terkadang memiliki aturan sendiri dalam menyelesaikan perkara, yaitu dengan musyawarah sehingga apa yang menjadi kesalahannya seperit misalnya mencuri maka barangnya dikembalikan lagi, apabila menipu maka diberikan ganti rugi. Sehingga dalam hal ini

\footnotetext{
4 Angrayni, L. (2016). Kebijakan Mediasi Penal dalam Penyelesaian Perkara Tindak Pidana Ringan Perspektif Restorative Justice. Jurnal Hukum Republica, 16(1), 88-102, hal. 101.

${ }^{5}$ Briliantari, N. P. M. A. dan Darmadi, A. A. N. O. Y. (2019). Mediasi Penal sebagai Alternatif Penyelesaian Perkara pada Tindak Pidana Body Shaming. E-Journal lmu Hukum Kertha Wicara, 8(8), 1-15.

6 Soekanto, S. (2007). Faktor-Faktor yang Mempengaruhi Penegakan Hukum. Jakarta: Raja Grafindo, hal. 5.
} 
masyarakat cenderung menyelesaikan perkara secara kekeluargaan dan tidak menempuh jalur hukum. ${ }^{7}$

Nelly Pinangkaan menjelaskan bahwa mediasi penal telah banyak digunakan khususnya setalah adanya Surat dari Kapolri No. Pol: B/3022/XII/2009/SDEOPS yang dikeluarkan pada 14 Desember tahun 2009. Surat ini berkaitan dengan penanganan kasus melalui Alternative Dispute Resolution (ADR). Surat dari Kapolri memiliki sifat parsial, selain itu mengandung prinsip terkait penanganan mediasi penal. Isi dari surat ini lebih mengutamakan terkait menyelesaikan perkara pidana dengan cara alternatif penyelesaian sengketa yang sejatinya berdasarkan kesepakatan antara pihak yang berperkara. Namun, perkara pidana memiliki variasi yang sangat beragam, dan apabila antara pihak yang berperkara tidak menemukan solusi atas permasalahannya, maka dapat diselesaikan melalui jalur hukum yang berlaku, dimana jalur ini diharapkan dapat menyelesaikan perkara secara profesional dan proporsional.

ADR merupakan penyelesaian sengketa alternatif, yang pada mulanya hanya dikenal pada wilayah hukum keperdataan. Ilmu hukum pidana yang terus berkembang dan disesuaikan dengan kondisi masyarakat, maka penyelesaian perkara pidana melalui cara alternatif diharapkan dapat menyelesaikan perkara tanpa harus menjatuhkan hukuman oleh hakim kepada pelaku. Solusi alternatif penyelesaian masalah melalui mediasi penal akhirnya menjadi cara lain penyelesaian perkara pidana tanpa harus masuk jalur hukum, tetapi tetap mempertimbangkan hak, keadilan dan memberikan manfaat bagi masyarakat secara luas. Alternatif penyelesaian perkara melalui mediasi penal ini mempunya prinsip "win-win solution", dan bukan "win-lose solution", yang artinya meskipun ada pihak yang bersalah dan dirugikan, tetapi penyelesaian dengan cara ini diharapkan memberikan keadilan bagi korban, dan pelaku juga tidak harus dijerat hukuman pidana menurut hukum berlaku.

Perkembangan hukum menuntut adanya penyelesaian perkara pidana yang secara filosofis dapat memuaskan semua pihak dan tidak selalu berakhir dengan penjatuhan pidana oleh hakim terhadap pelaku. Sehingga ADR dipandang sebagai jalan atau alternatif selain penyelesaian melalui proses litigasi yang dapat menyelesaikan perkara pidana secara berkeadilan dan memberikan kemanfaatan bagi masyarakat luas berdasarkan prinsip win-win solution (solusi menang-menang) dan bukan win-lose solution (solusi menang-kalah). ${ }^{8}$

Disisi lain, Hariyanto dan Yogantara menjelaskan bahwa terkait dengan mediasi menal belum ada aturan khususnya undang-undang yang bisa mengatur secara rinci. Meskipun pada praktiknya sering dilakukan penyelesaian perkara melalui mediasi penal. Dasar hukum yang digunakan dalam praktik mediasi penal tercantum pada kewenangan aparat penegak hukum, khususnya polisi yang diatur dalam UndangUndang No. 2 Tahun 2002 tentang Keplisian Republik Indonesia dan Kita Undang-

\footnotetext{
7 Pinangkaan, N. Op.Cit, hal. 180.

8 Mahendra, A. P. (2020). Mediasi Penal pada Tahap Penyidikan Berlandaskan Keadilan Restoratif. JuristDiction, 3(4), 1153-1178, ha: 1156
} 
Undang Hukum Acara Pidana (KUHAP). Dasar hukum lain yang digunakan adalah Peraturan Kapolri Nomor 3 Tahun 2014 tentang Pemolisian Masyarakat dan Surat Kepolisian RI No. Pol: B/3022/XXI/2009/ SDEOPS, tanggal 14 Desember 2009, Perihal Penanganan Kasus Melalui Alternative Dispute Resolution (ADR). Meski demikian, mediasi penal yang diatur dalam beberapa peraturan tersebut memiliki sifat eksplisit, dan tidak memberikan peraturan yang rinci serta tegas terkait pelaksanaan mediasi penal. ${ }^{9}$

Peraturan-peraturan yang ada membuat medias penal tidak memiliki dasar hukum yang kuat. Adanya perubahan dan perubahan terkait dengan hukum pidana (KUHP) dan KUHAP telah menunjukkan terkait dengan penggunaan mediasi penal pada hukum di masa depan. Hal ini dapat dijelaskan karena adanya asa "pemberian maaf atau pengampunan oleh hakim" ("recshterlijk pardon" atau "judicial pardon" yang mengatur tentang tujuan dan pedoman pemidanaan serta penyelesaian perkara di luar peradilan hukum (afdoening buiten process)

Tidak ada dasar hukum yang kuat yang mengatur mengenai mediasi penal. Pembaharuan hukum pidana materiil (KUHP) dan formil (KUHAP) secara implisit telah mengarahkan penggunaan mediasi penal dalam hukum pidana di masa yang akan datang, hal ini terlihat dari adanya asas "pemberian maaf atau pengampunan oleh hakim ("rechterlijk pardon" atau "judicial pardon"), diaturnya tujuan dan pedoman pemidanaan dan penyelesaian di luar pengadilan (afdoening buiten process). ${ }^{10}$

Berdasarkan pemaparan di atas, menjadi menarik apabila mengkaji lebih lanjut tentang eksistensi mediasi penal dalam penanganan tindak pidana dan relevansi mediasi penal. Adapun perumusan permasalahan pada studi kali ini yaitu bagaimana eksistensi mediasi penal dalam penanganan tindak pidana di Indonesia dan bagaimana relevansi mediasi penal dengan upaya mewujudkan keadilan restoratif dalam penanganan tindak pidana.

\section{Metodologi}

Jenis penelitian normatif dipilih untuk digunakan pada studi ini. Pendekatan normatif merupakan pendekatan yang mengkaji nilai-nilai yang sesuai dengan masalah penelitian dan cara meneliti data sekunder atau bahan pustaka. Pendekatan lain yang digunakan yaitu pendekatan yuridis, dengan melihat Undang-undang yang sesuai atau data primer yang berkaitan dengan masalah yang diteliti oleh peneliti. Data yang digunakan adalah data sekunder dan metode yang digunakan pada penelitian ini adalah library research.

\footnotetext{
9 Hariyanto, D. R. S. dan Yogantara, P. (2019). Mediasi Penal dalam Ius Constitutum dan Ius Contituendum di Indonesia. Jurnal Kertha Wicaksana, 13(1), 26-37, hal: 36.

10 Ibid.
} 


\section{Analisis dan Hasil}

\subsection{Eksistensi Mediasi Penal dalam Penanganan Tindak Pidana di Indonesia}

Permasalahan terkait tindak pidana secara filosofi hukum positif belum bisa terselesaikan melalui langkah-langkah di luar jalur litigasi. Dalam kasus tertentu penyelesaian perkara pidana mungkin dapat diselesaikan di luar pengadilan apabila kasus tersebut dapat ditengahi dengan baik dan mencapai kesepakatan antara pelaku dengan korbannya. Penegakan hukum di Indonesia dalam kasus pidana dapat diselesaikan di luar jalur litigasi dengan adanya diskresi dari polisi sebagai aparat penegak hukum, juga terjadi dalam kasus hukum adat yang memiliki mekanisme perdamaian sendiri, atau dalam hal lainnya. ${ }^{11}$ Contoh lembaga adat yang mengadopsi mediasi penal dalam penyelesaian perkara perzinaan melalui lembaga adat Megou Pak Tegamo'an. Lembaga adat ini memiliki hukum yang berlaku dalam lingkungannya, dimana mereka memiliki mekanisme penyelesaian kasus perzinaan tanpa adanya campur tangan dari aparat penegak hukum. Adapun mekanisme penyelesaian kasus perzinaan dilakukan dengan dilakukannya musyawarah yang melibatkan Kepala Tiyuh dan tokoh adat, kemudian menentukan waktu dan tempat untuk menyelesaikan perkara, mengundang keluarga dari pihak yang menjadi korban dan pelaku, setelah itu menjelaskan terkait dengan hukum adat Megou Pak Tegamo'an dan menetapkan hukuman serta adanya perjanjian damai antara pihak pelaku dan pihak korban. ${ }^{12}$

Mediasi di lembaga adat memiliki fungsi sebagai sarana partisipasi masyarakat di adat untuk mewujudkan keadilan dilingkungannya. Lembaga adat memainkan peran dalam mengatur ketertiban yang ada diwilayahnya, meskipun dalam beberapa kasus tetap mengambil langkah ke lembaga penegak hukum. Lembaga adat yang merupakan hasil kesepakatan penduduk di suatu wilayah terkadang dibeberapa daerah sudah terbentuk sudah sangat lama, hal ini membuat masyarakat diwilayah tertentu mulai mengatur terkait dengan urusan perilaku yang ada di wilayahnya, termasuk dalam proses penyelesaian kasus-kasus yang terjadi diwilayahnya, lembaga adat berdasarkan sejarahnya yang panjang memiliki pendekatan tersendiri yang mana hal ini juga di akui pemerintah. Proses peradilan dalam lembaga adat menjadi salah satu upaya alternatif dalam menyelesaikan suatu perkara di suatu wilayah tertentu. Meski demikian begitu beragamnya adat dan istiadat di Indonesia, proses penanganan suatu perkara dapat bermancam-macam yang terkadang bisa lebih ringan dari pada peradilan hukum atau bahkan lebih berat. Namun tujuan dari mekanisme hukum dalam lembaga adat tujuannya agar masyarakat diwilayahnya dapat hidup rukun kembali.

\footnotetext{
11 Mulyadi, L. (2013) Mediasi Penal dalam Sistem Peradilan Pidana Indonesia: Pengkajian Asas, Norma, Teori dan Praktik. Yustisia, 2(1), 1-14, hal. 4.

12 Berlian, S., Andrisman, T., dan Negara, D. Q. (2019). Mediasi Penal Melalui Lembaga Adat dalam Penyelesaian Kasus Perzinaan, Jurnal Law Reform, 2(2), hal. 19.
} 
Contoh lain yang penyelesaian sengketa melalui mediasi yaitu pada lembaga adat di Aceh. Terdapat empat bentuk praktik masyarakat Aceh dalam menyelesaikan sengketa yaitu di'iet, sayam, suloh dan peumat jaroe. Ini dimulai berdasarkan ulama Aceh pada masa dahulu yang memiliki peran mediator dalam menyelesaikan konflik yang timbul di masyarakat Aceh. Kamaruddin menjelaskan bahwa peradilan yang didasarkan atas hukum adat yang dijalankan melalui lembaga adat memiliki tujuan bukan hanya menyelenggarakan dan menjalankan kegiatan pemerintah adat, tetapi memiliki tanggung jawab sebagai penengah dalam suatu perkara yang ada di wilayahnya, sehingga tercipta masyarakat yang rukun. ${ }^{13}$

Contoh kasus lain dalam mediasi penal pernah terjadi dalam kasus $\mathrm{Ny}$. Ellya Dado, dalam hal ini perkara tersebut sudah masuk dalam peradilan, tetapi antara $\mathrm{Ny}$. Ellya dan pihak yang berperkara sudah terjadi kesepakatan damai. Dalam hal ini hakim memberikan pertimbangan untuk tindak pidana yang terjadi antara $\mathrm{Ny}$. Ellya dan pihak yang berperkara meskipun terbukti suatu tindak pidana, tetapi sudah tidak lagi dianggap pelanggaran atau kejahatan, maka dari itu pelaku sudah terlepas dari segala tuduhan hukum. Mediasi penal ini dijelaskan dalam rancangan KUHAP tentang mediasi penal dalam Pasal 111 yang menjelaskan bahwa "penyidik berwenang untuk menghentikan penyidikan karena tidak terdapat cukup bukti atau peristiwa tersebut ternyata bukan merupakan tidak pidana atau penyidikan dihentikan demi hukum".

Terkait dengan rancangan KUHAP juga dijelaskan bahwa penghentian penyidikan dapat terjadi dikarenakan putusan hakim pada saat pra peradilan yang diminta oleh pelapor/korban, dimana hal tersebut dapat terjadi karena adanya mediasi antara korban dengan tersangka. Pada pasal 111 ayat (3) juga dijelaskan bahwa mediasi dapat dilakukan apabila tindak pidana tergolong ringan, ancaman pidananya maksimal adalah 4 (tahun) atau hanya diancam dengan pembayaran denda, kerugian akibat tindak pidana sudah diganti, serta apabila tersangka berumur lebih dari 70 tahun ketika melakukan tindak pidana. Dapat dijelaskan bahwa apabila ada pelaku yang sudah ditetapkan menjadi tersangka, kemudian dalam proses penyidikan terjadi kesepakatan antara korban dan pelaku, dimana pelaku mengganti kerugian korban, atau korban berusaha memaafkan atas dasar tertentu dan apabila sesuai dengan pasal $111 \mathrm{KUHAP}$, maka pelaku yang sudah masuk dalam jalur hukum dapat terlepas dari segala gugatannya.

Berdasarkan rancangan tersebut mediasi penal dapat terjadi pada saat penyidik melakukan tugasnya. Penyidikan dapat dihentikan pada kasus yang terjadi karena pengaturannya ada dalam rancangan KUHAP. Rancangan KUHAP sendiri memiliki tujuan agar terwujudnya hukum yang memberikan manfaat dan keadilan. Dalam hal ini apabila mediasi sudah dilakukan dan antara pelaku dan korban sudah terjadi damai dan kesepakatan sesuai dengan kasus yang terjadi, dalam persidangan pelaku dapat terbebas dari tuntutan.

${ }^{13}$ Kamaruddin, dkk. (2013). Model Penyelesaian Konflik di Lemabga Adat. Walisongo, 21(1), 39-70, hal: 49. 
Dalam kasus lain, berdasarkan pasal 111 KUHAP, apabila antara pihak berperkara tidak melakukan mediasi penal. Adanya peraturan seperti tindak pidana dilakukan oleh orang yang berusia di atas 70 tahun, tindak pidana masuk dalam kategori ringan dimana pidananya maksimal hanya 4 (tahun), maka mediasi dapat dilakukan pada tingkat penuntutan atau pada saat persidangan hakim memberikan kepastian hukum untuk pelaku tidak diberikan hukum, tetapi dengan pertimbangan kepastian, kemanfaat, dan keadilan hukum. Penjelasan dari hal ini bahwa apabila media dilaksanakan di tingkat penuntutan, maka asas yang digunakan merupakan asas oprotunitas, dimana ini merupakan ajaran yang memberikan kewenangan kepada jaksa untuk mengesampingkan suatu perkara pidana, meskipun bukti yang terkumpul cukup. Hal ini dilakukan demi kepentingan umum dimana pelaku dapat dibebaskan baik dengan syarat maupun tanpa syarat.

Pasal 35 huruf c UU No. 16 tahun 2004 tentang Kejaksaan RI memberikan penjelasan terkait asas oportunitas. Adapun penjelasannya bahwa Jaksa Agung memiliki tugas dan wewenang untuk mengesampingkan suatu perkara dengan mempertimbangkan adanya kepentingan umum, hal ini dikenal dengan "seponering". Sebagai contoh, Hakim Bismar Siregar dalam kasusnya pernah memberikan putusan bahwa penting untuk mempertimbangkan mediasi pena pada persidangan untuk menyelesaikan konflik melalui musyawarah dengan adanya pertimbangan kesadaran terhadap manfaat dan saling memaafkan. ${ }^{14}$

Mediasi sebagai salah satu cara untuk menyelesaikan sengketa lebih dulu dikenal dalam sistem hukum perdata dengan adanya lembaga damai dalam Pasal 130 HIR/154 RBg dengan terbitnya Perma No. 1 Tahun 2008 tentang Mediasi dan telah diubah dengan Perma No. 1 Tahun 2016 tentang prosedur mediasi yang mewajibkan semua sengketa perdata yang diajukan ke Pengadilan tingkat pertama melalui upaya perdamaian dengan bantuan mediator, dan diundangkannya melalui UU No. 3 Tahun 1999 tentang Arbitrase dan Alternatif Penyelesaian Sengketa.

Mediasi penal sebagai instrumen keadilan restoratif dikenal dengan beberapa istilah diantaranya adalah Victim-Offender Mediation (Mediasi antara Korban dan Pelaku). Mediasi digunakan sebagai kesempatan bagi pelaku dan korban untuk bertemu dan menyelesaikan sengketa dan membangun pendekatan yang mereka buat sendiri dalam mencapai keadilan yang mereka inginkan yang bertujuan mendayagunakan para pihak, mengutamakan dialog dan pemecahan masalah secara musyawarah. Mediasi sebagai salah satu cara penyelesaian sengketa pada dasarnya menggunakan prinsip dalam musyawarah mufakat, dimana para pihak saling berkompromi untuk mencari solusi terbaik yang seadil-adilnya.

Eksistensi dari mediasi penal dikaji berdasarkan berbagai padangan, baik dari sisi filosofi, sosilogi dan yuridis. Mediasi penal dipandang dari sisi filosofi menerapkan asas "win-win solution", bukan malah "win-lost" yang biasanya tercapai pada peradilan

14 Purnomo, B. S. H. (2018). Kedudukan Mediasi Penal dalam Sistem Peradilan di Indonesia. Jurnal Ilmiah Ilmu Sosial, 4(2), 187-199, hal: 198. 
formal melalui proses hukum litigatif atau bahkan dalam kasus tertentu antara pelaku dan korban mendapatkan "lostlowst (kalah-kalah)". Mediasi penal dapat menjadi jalur yang memberikan kesepakatan puncak keadilan tertinggi antara pelaku dan korban dalam suatu tindak pidana tertentu. Adanya media penal baik pelaku atau korban mencari solusi terbaik dan menjadi alternatif dalam menyelesaikan suatu perkara pidana tertentu. Manfaat dari adanya mediasi penal yaitu tercapainya solusi korban dalam hal ini dapat mengajukan pergantian hak yang hilang akibat suatu tindak pidana tertentu, kemudian kompensasi tersebut disepakati, dan dimusyawarahkan antara pelaku dan korban agar mencapai solusi yang baik (win-win solution). Mediasi penal juga alternatif penyelesaian kasus pidana secara sederhana, cepat memiliki biaya ringan karena pihak yang dilibatkan lebih sedikit dibandingkan melalui jalur litigasi, sehingga dapat mencapai tingkat penyelesaian perkara pidana secara efektif dan efisien, tetapi memberikan manfaat dan keadilan yang tinggi.

Menurut pandangan dalam perspektif sosiologis, media penal terkait dengan sejarah akan budaya yang melekat pada masyarakat di suatu wilayah tertentu di Indonesia. Aspek ini berorientasi pada nilai kekeluargaan, mengedepankan musyawarah untuk mencari solusi dari suatu perkara dalam suatu sistem sosial. Terkadang aspek sosiologis dalam mediasi penal juga berkaitan dengan dimensi kearifan lokal hukum adat. Berdasarkan sejarah hukum, awal mula suatu hukum berlaku didasarkan dari hukum adat sebagai cerminan atas kesadaran terkait peraturan masyarakat di suatu wilayah. Aspek sejarah hukum itu bermula terkait dengan Theorie Rexeptie dari Snouck Hurgronje, yang menjelaskan tentang hukum adat yang menjadi norma sosial di masyarakat memberikan peran yang berfungsi dalam pengendalian sosial. 15

Hukum adat lahir sebagai konsekuensi logis dari kearifan lokal yang didasarkan atas perkembangan perilaku dan normal dalam suatu sistem sosial. Sistem sosial yang terjadi merupakan perilaku interaksi yang melibatkan sejumlah individu dalam suatu wilayah tertentu. Sistem tindakan manusia Menurut Talcott Parsons merupakan bagian yang tersusun dari sejumlah bagian yang disebut sub-sistem. Masing-masing sub-sistem mempunyai peran tersendiri terhadap sistem keseluruhan. Berikut ada empat peran dari sub-sistem. ${ }^{16}$

a. Adaptation, atau disebut fungsi adaptasi dimana fungsi ini mengharuskan individu dalam sistem sosial menyesuaikan diri terhadap situasi di lingkungan, agar dapat menghadapi lingkungannya tersebut.

b. Goal Attainment, atau disebut fungsi pencapaian tujuan yang dijelaskan bahwa individu dalam menjalankan kehidupannya diarahkan pada tujuannya atau sasaran, tetapi dalam hal ini fokus dari pencapaian tujuan bukan saja individu

15 Salman, H. R. Otje. (2007). Kesadaran Hukum Masyarakat Terhadap hukum Waris. Bandung: PT Alumni, hal. 21.

16 Zilfatun, N. (2003). Sosiologi Hukum, Yogyakarta: Teras, hal. 4. 
melainkan sekelompok anggota secara bersama-sama menetapkan tujuan dalam sistem sosial.

c. Inegration, atau disebut fungsi integrasi yang merupakan pengakomodasian berbagai faktor untuk mencapai tujuan. Dalam fungsi ini memiliki bagian atas berbagai unit dalam sistem sosial yang saling berkoordinasi terkait dengan kontribusi dalam suatu anggota kelompok sehingga dapat berfungsi secara keseluruhan.

d. Pattern Maintenance or Latency, yaitu fungsi pemeliharaan pola atau latensi yang dijelaskan sebagai proses pemeliharaan pola yang sudah terbentuk dalam sistem sosial berdasarkan nilai-nilai yang muncul didalamnya.

Merujuk pada empat fungsi di atas, adanya hukum adat menjadikan sistem sosial yang ada didalamnya saling berintegrasi dalam mencapai tujuan bersama. Peraturan atau hukum dalam adat menjadi akomodasi dalam sistem sosial di masyarakat. Fungsi hukum ini berpandangan bahwa kaidah dalam hukum adat berfungsi sebagai alat untuk mengoreksi apabila terjadi penyimpangan yang dapat merugikan anggota dalam kelompok. Peraturan atau kaidah yang timbul karena adanya interaksi sosial menuntut untuk terwujudnya peran tertentu, sehingga kaidah yang berlaku menjadi kerangka orientasi perilaku manusia sebagai anggota dalam sistem kemasyarakatan. ${ }^{17}$

Hukum adat sebagai kearifan lokal berasal dari pandang kosmis, religius dan magis yang terkait dengan aspek sosiologis. Hal tersebut membentuk masyarakat di Indonesia memiliki pandangan dan budaya sesuai lingkungannya. Dalam hukum adat mediasi penal menjadi bagian atau hasil dari perilaku manusia di wilayah tertentu, hal ini bukan hal sudah banyak diimplementasikan di berbagai wilayah di Indonesia. Bahkan istilah mediasi penal sudah melekat dalam beberapa budaya dan tradisi lokal seperti masyarakat Aceh, Papua, Jawa, Bali, Sumatera Barat, Lombok, Sulawesi dan berbagai daerah lain di Indonesia yang sejatinya memiliki keanekaragaman budaya. Dikancah internasional, mediasi penal juga sudah dikenal sejak lama, sebagai bukti pada tahun 1995 terjadi konferensi Persatuan Bangsa-Bangasa (PBB) yang berbicara terkait dengan mediasi, restitusi, konsiltas dan kompensasi dalam peradilan pidana. Pemaparan tersebut tertuang dalam dokumen A/CONF 169/6 yang mana menjelaskan bahwa setiap negara harus mempertimbangkan terkait "“ privatizing some law enforcement and justice functions" dan "alternative dispute resolution/ADR" Kemudian dalam Konferensi Internasional Pembaharuan Hukum Pidana tahun 1999 dikemukakan bahwa salah satu unsur kunci dari agenda baru hukum pidana, yaitu perlunya memperkaya sistem peradilan formal dengan sistem atau mekanisme informal dengan standar-standar hak asasi manusia.

Ide ini mengidentifikasikan adanya sembilan strategi pengembangan dalam melakukan "pembaharuan hukum pidana melalui pengembangan restrative justice, alternative dispute to custody, alternative ways of dealing with juveniles, dealing with violent

17 Mulyadi, L. Op.Cit., hal. 4. 
crime, reducing the prison population, the proper management of prisons dan the role of civil in penal reform". Terkait dengan mediasi penal juga tertuang dalam perkembangan hukum pidana yang terjadi pada tahun 2000 dalam kongres PBB ke sepuluh yang tercantum dalam dokumen A.CONF.187/4/Rev/3. yaitu “dikemukakan untuk memberikan perlindungan kepada korban kejahatan, hendaknya diintrodusir mekanisme mediasi dan peradilan restoratif (restorative justice)". Adanya tindak lanjut dari pertemuan internasional di PBB tersebut, maka didorong untuk munculnya dokumen internasional yang berkorelasi dengan peradilan restoratif dan mediasi dalam perkara pidana berupa "the Recommendation of the Council of Eure 1999 No. R (99) 19 tentang Mediation in Penal Matters". Perjanjian lain juga dilakukan oleh the EU Framework Decision 2001 tentang "the Standing of Victim in Criminal Proceedings" dan the UN Principles 2002 (Resolusi Ecosoc 2002/12) tentang "Basic Principles on the Use Restorative Justive Programmes in Criminal Matters". Berdasarkan rekomendasi di atas, maka beberapa negara mengenalkan mediasi penal dalam Undang-undang yang berlaku dinegaranya masing-masing seperti negara Austria, Jerman, Belgia, Perancis dan Polandia. ${ }^{18}$

Secara yuridis, mediasi penal dijelaskan oleh Barda Nawawi Arif bahwa di beberapa negara telah dipergunakan alternatif penyelesaian perkara pidana melalui mediasi serta telah ada ketentuan hukumnya. Beberapa penempatan mediasi penal dalam Undang-undang yang digunakan di beberapa negara lain. Sebagai contoh di negara Jerman, Polandia, Austria dan Finlandia mediasi penal ditempatkan pada ketentuan peradilan anak "the Juvenile Justice Act" dan dalam ketentuan hukum pidana "the Code of Criminal Procedure", di negara Belgia, Perancis, Austria, dan Polandia di tempatkan dalam "the criminal code" atau KUHAP, bahkan di negara Norwegia medias penal memiliki aturan khusus yang di atur dalam "the mediation act".19

Barda Nawawi Arif menjelaskan bahwa mediasi penal dalam perkara pidana di Indonesia telah diterapkan dalam sistem peradilan anak dengan Diversi yang memungkinkan penyelesaian perkara di luar persidangan dengan adanya kesepakatan antara korban dengan pelaku untuk mengakhiri sengketa. Hal ini diatur dalam "UU No. 11 Tahun 2012 tentang Sistem Peradilan Pidana Anak", yang mengatur tentang kewajiban penyelesaian melalui musyawarah diversi. Ketentuan itu dijelaskan sebagai "bentuk dari mediasi penal sekalipun istilah yang digunakan berbeda. Konsep musyawarah diversi ini berkembang dari konsep musyawarah dan mufakat yang sudah mengakar dalam penyelesaian konflik di daerah-daerah melalui hukum adat, kearifan lokal hingga pertimbangan hukum agama. Konsep musyawarah mufakat ini sebetulnya adalah warisan dari nenek moyang Indonesia yang sebetulnya tidak ada bedanya dengan mediasi". ${ }^{20}$

18 Mulyadi, L. Op.Cit., hal. 5.

${ }^{19}$ Arief, B. N. (2016). Bunga Rampai Kebijakan Hukum Pidana, Jakarta: Prena Media Group, hal: 12.

20 Rado, R. H., Arief, B. N., dan Soponyono, E. (2016). Kebijakan Mediasi Penal terhadap Penyelesaian Konflik Sara di Kepulauan Kei dalam Upaya Pembaharuan Hukum Pidana nasional. Jurnal Law Reform, 12(2), 266-276, hal. 270. 
Dalam pasal lain, yaitu Pasal 7 ayat (1) UU a quo menjelaskan bahwa "penegak hukum mewajibkan dilakukannya diversi pada tingkat penyidikan, penuntutan dan pemeriksaan perkara Anak di Pengadilan Negeri khusus untuk tindak pidana anak yang diancam dengan pidana penjara di bawah 7 (tujuh) tahun dan bukan merupakan pengulangan tindak pidana (residivis)". Ketentuan tersebut mengubah pendekatan yang digunakan dari retributive justice (pembalasan) menjadi pendekatan restorative justice (pemulihan). Keadilan restoratif merupakan "ruh" dari mediasi penal, yang juga dijelaskan secara filosif sebagai pendekatan "win-win". Pemikiran mengenai keadilan restoratif menjelaskan bahwa keadilan tidak hanya digali dari sisi victim-centered, melainkan turut memperhatikan sisi pelaku. Hal ini dilakukan agar pelaku mengakui dan bertanggungjawab atas tindakan pidana yang dilakukannya kepada korban atau masyarakat.

Perkara pidana lain yang mengambil konsep mediasi penal terdapat pada pidana kekerasan dalam rumah tangga, sebagaimana diatur dalam UU No. 3 Tahun 2004 tentang Penghapusan Kekerasan dalam Rumah Tangga, diatur pada Pasal 51-53 bahwa "tindakan kekerasan fisik, psikis dan kekerasan seksual dikategorikan ke dalam delik aduan. Untuk menjamin kebaikan dan keutuhan rumah tangga, penyelesaian pidana kekerasan dalam rumah tangga ini seringkali diselesaikan melalui mediasi". Hal ini tentu agar pertikaian di dalam masalah keluarga sebisa mungkin tidak memperbesar hingga di ranah kejaksaan. Konflik dalam rumah tangga juga seharusnya menjadi ranah personal, sehingga sebisa mungkin tidak melibatkan lembaga hukum dan diselesaikan secara kekeluargaan.

Secara yuridis, mediasi penal di Indonesia memang belum mendapatkan posisi dasar hukum yang kuat dan lebih menggantungkan pelaksanaannya pada praktik penegakan hukum, tetapi pada praktiknya mediasi penal ini banyak diterapkan pada pelbagai kasus pidana. Konsekuensi maraknya penggunaan mediasi penal sebagai ADR, menjelaskan bahwa saat ini perbedaan antara hukum perdata dan pidana menjadi semakin menipis. Adanya pengakuan terkait dengan mediasi penal tidak memiliki dasar yang kuat untuk saat ini, membuat mediasi penal terkesan menguntungkan ketika berkaitan dengan penegakan hukum pidana. Dimana mediasi penal dapat dibilang terjadi hanya dalam "law in concerto", yaitu penegakan hukum yang masih dipengaruhi oleh kebiasaan/budaya.

Mediasi penal yang paling sering dilakukan adalah di tingkat penyidik kepolisian. Hal ini terjadi karena penyidik merupakan pintu utama dalam sistem peradilan pidana. ${ }^{21}$ Apabila suatu kasus telah tercatat oleh penyidik dan kemudian diserahkan kepada kejaksaan, maka kasus tersebut dapat diselesaikan di dalam ranah pengadilan. Tetapi pada kenyataannya mediasi penal terjadi, ketika suatu kasus diketahui oleh penyidik kemudian dilakukan mediasi antara pihak yang

${ }^{21}$ Eryke, H. dan Herlambang. (2020). Mediasi Penal Bagi Anak Berkonflik dengan Hukum. University of Bengkulu Law Journal, 5(1), 47-61. Hal: 60 
bersangkutan, sehingga pertikaian yang terjadi tidak lanjut ke tahap selanjutnya di dalam sistem peradilan.

Momentum munculnya mediasi penal terjadi ketika "Kepolisian Negara Republik Indonesia mengeluarkan Surat Kapolri No. Pol: B/3022/XII/2009/SDEOPS tanggal 14 Desember 2009 tentang Penanganan Kasus Melalui Alternative Dispute Resolution (ADR) yang menekankan penyelesaian kasus pidana dengan menggunakan ADR sepanjang disepakati oleh pihak-pihak yang berperkara. Lembaga Kepolisisan dalam hal ini memiliki kewenangan untuk menentukan apakah suatu perbuatan diteruskan atau tidak diteruskan dalam proses peradilan pidana dengan alasan tertentu". Maksud dari Perkapolri ini menjelaskan bahwa jika petugas kepolisian menemukan adanya konflik, maka petugas polisi dapat memutuskan apakah dilakukan mediasi penal atau diteruskan ke kejaksaan.

Berdasarkan paparan tersebut, maka dapat dijelaskan bahwa mediasi penal sangat dibutuhkan dalam penyelesaian perkara pidana secara alternatif. Manfaat terkait adanya efektif, efisiensi, penghapusan kewenangan untuk menuntut menjadikan mediasi penal cara alternatif yang sangat baik untuk kasus-kasus tertentu. KUHP 2008 memiliki pandangan serupa dengan tujuan dari mediasi penal, dimana digunakan sebagai sebab dihapuskannya kewenangan penuntutan, tetapi ini masih menjadi cita-cita dimasa depan. Pasal 145 KUHP 2008 dalam huruf d, e, dan f menjelaskan bahwa "kewenangan penuntutan gugur jika: (d) penyelesaian di luar proses, (e) Maksimum pidana denda dibayar dengan suka rela bagi tindak pidana yang dilakukan hanya diancam dengan pidana denda paling banyak kategori II, (f) maksimum pidana denda dibayar dengan suka rela bagi tindak pidana yang diancam dengan pidana penjara paling lama 1 (satu) tahun atau pidana denda paling banyak kategori III". Disisi lain terkait dengan penghapusan wewenang dalam menjalankan pidana bagi pelaku yang sudah dijatuhkan putusan hakim berupa penjara atau denda, mediasi penal menjadi tahap eksekusi yang sejalan dengan Pasal 57 RUU KUHP tentang Perubahan dan Penyesuaian Pidana. Ketentuan ini menjelaskan bahwa pelapor dapat mencabut atau mengganti jenis pidana atau tindakan lainnya. ${ }^{22}$

\subsection{Relevansi Mediasi Penal dengan Upaya Mewujudkan Keadilan Restoratif dalam Penanganan Tindak Pidana}

Berbicara mengenai relevansi mediasi penal sebagai upaya mewujudkan keadilan restoratif, maka apakah semua perkara pidana dapat diselesaikan melalui jalan mediasi atau hanya perkara tertentu. Berdasarkan pemaparan sebelumnya, dimana belum ada aturan yang secara khusus mengatur mengenai mediasi penal, meskipun mediasi penal sendiri dalam menyelesaikan perkara pidana sudah eksis. Inti dari penggunaan mediasi penal dalam perkara pidana terletak pada apakah hal tersebut dikehendaki oleh para pihak (pelaku dan korban) serta untuk mencapai kepentingan yang lebih luas yaitu untuk menjaga ketertiban dalam masyarakat.

22 Pinangkaan, N. Op.Cit, hal. 180. 
Keadilan restoratif merupakan suatu model pendekatan yang muncul pada era tahun 1960-an. Keadilan restoratif muncul sebagai upaya penyelesaian perkara pidana. Berbeda dengan pendekatan yang dipakai sistem peradilan konvensional, dimana pendekatan ini menekankan pada adanya partisipasi langsung dari pelaku. Keadilan restoratif bertujuan untuk mewujudkan pemulihan kondisi korban kejahatan, pelaku dan masyarakat berkepentingan melalui proses penyelesaian perkara yang tidak hanya berfokus pada mengadili dan menghukum pelaku. ${ }^{23}$

Menurut pernyataan Menteri Hukum dan Hak Asasi Manusia RI menjelaskan bahwa "perlu adanya perhatian pada penyelesaian perkara pidana melalui mekanisme lembaga restorative justice sebagai upaya yang perlu direspons secara positif oleh seluruh elemen penegak hukum dan pencinta keadilan, ${ }^{24}$ restorative justice atau proses peradilan yang memulihkan akan dapat mengurangi beban sosial-ekonomis negara dan energi penegak hukum dalam memberikan keadilan bagi masyarakat, untuk itu keberadaan lembaga restorative justice prosedurnya perlu dimasukkan dalam sistem peradilan pidana".

Secara umum prinsip dalam "restoratie justice" yang menggunakan mediasi tidak semua perkara, tetapi ada beberapa perkara yang sesuai dengan ketentuan sebagai berikut, yaitu: mediasi tercipta atas dasar kesepakatan dimana korban telah menyetujuinya, apabila berkaitan dengan kekerasa maka harus dihentikan, pelaku harus bertanggungjawab atas hak-hak korban yang hilang akibat pidana yang dilakukannya, dalam hal ini korban tidak dipersalahkan tetapi hanya pelaku saja yang disalahkan, dan mediasi dilaksanakan atas persetujuan korban.

Berdasarkan prinsip dalam "restorative justice" di atas, maka alternatif penegakan hukum melalui mediasi penal memiliki martabat yang mendukung korban, dimana korban harus menjadi prioritas. Mediasi penal juga terdiri dari sipiritual yang dapat mengembalikan dan rasa percaya diri korban, dibandingkan dia harus dihukum penjara yang membuatnya merasa memiliki aib. Urgensi dari mediasi penal untuk mencapai restorative justice adalah usaha yang dilakukan agar mencapai penyelesaian perkara pidana yang bertujuan untuk win-win solution. Tetapi mediasi penal tidak dapat dilakukan untuk perkara yang memiliki dampak besar terhadap masyarakat, atau negara seperti tindak pidana korupsi. Hal ini tidak mungkin dilakukan melalui mediasi penal, karena korban korupsi bukan merupakan individu tetapi rakyat banyak dan hak sosial ekonomi telah diambil oleh pelaku yang dalam hal ini koruptor.

Sanksi pidana bersifat reaktif yang lebih ditujukan terhadap suatu perbuatan, sedangkan sanksi tindakan bersifat restoratif lebih mengedepankan antisipatif terhadap pelaku perbuatan tersebut. Fokus sanksi pidana menekankan pada perbuatan pelaku melalui sebuah penderitaan untuk membuat jera, sedangkan fokus restoratif adalah upaya memberikan pertolongan agaria berubah dan memberikan perlindungan

23 Sholehuddin, M. (2003). Sistem Sanksi dalam Hukum Pidana, Ide Dasar Double Track System dan Implementasinya, Jakarta: PT Rajagrafindo hal. 26.

24 Prihatini, L. (2015). Perspektif Mediasi Penal dan Penerapannya dalam Perkara Pidana. Pakuan Law Review, 1(1), 1-46., hal: 38 . 
kepada mereka yang menjadi korban. Hal ini dikemukakan pula oleh J.E.Jonkers bahwa sanksi pidana dititikberatkan untuk kejahatan yang dilakukan sedangkan sanksi tindakan dititikberatkan pada tujuan yang bersifat sosial. Jadi dengan adanya pendekatan restoratif dalam sistem peradilan pidana, maka hak-hak korban pun dapat menjadi fokus dalam putusan hakim sehingga sistem peradilan pidana tidak hanya mengatur mengenai sanksi atas perbuatan tapi tanggung jawab pelaku kepada mereka yang dirugikan akibat perbuatannya. Menurut peneliti paradigma restoratif lebih memiliki dimensi yang lengkap yaitu penerapan sanksi dan pemulihan para korban. ${ }^{25}$

Muzakir mengemukakan kategori yang dapat diselesaikan melalui mediasi penal dalam rangka untuk mewujudkan keadilan restoratif terdiri dari delapan kriteria yaitu: a) Pelanggaran hukum yang dapat diselesaikan dengan mediasi penal termasuk pada kategori delik aduan, delik ini bersifat relatif dan absolute; b) Mediasi penal berlaku apabila perkara pidananya termasuk dalam kategori "pelanggaran" dan tidak termasuk "kejahatan", dimana pelanggaran hanya diberikan pidana denda; c) Mediasi penal berlaku jika pelaku sudah membayarkan denda yang menjadi ancaman atas pelanggaran yang terjadi sesuai Pasal $80 \mathrm{KUHP}$; d) Mediasi penal hanya berlaku apabila pidana yang dilakukan termasuk tindak pidana di bidang hukum administrasi, dimana penempatan pelaku diberikan sanksi sebagai ultimum remedium; e) Mediasi penal dapat dilakukan apabila tindak pidana yang dilakukan masuk kategori ringan, dan polisi sebagai aparat penegak hukum dapat melaksanakan wewenangnya dalam melakukan diskresi terhadap pelaku; f) Mediasi penal yang dilakukan jika tindak pidana yang dilakukan biasa dan dapat dihentikan, atau berhenti diproses di pengadilan berdasarkan wewenang Jaksa Agung; g) Mediasi penal hanya dilakukan apabila termasuk dalam kategori pidana adat, dimana pidana ini hanya lebih baiknya diselesaikan oleh lembaga adat di wilayah yang bersangkutan.

Agus Raharjo menjelaskan enam prinsip yang dilakukan dalam proses penyelesaian kasus dengan mediasi penal (non litigasi) dapat mendukung upaya tercapainya keadilan restoratif. Prinsip ini dilakukan untuk melihat sejauh mana relevansi mediasi penal dapat digunakan untuk memberikan keadilan dalam menyelesaikan suatu perkara. Pertama, untuk menggunakan mediasi penal dalam penyelesaian perkara pidana diteliti terkait perkara yang dilakukan masuk dalam kategori delik formil atau materiil. Baik keduanya yaitu delik formil atau materiil dapat terjadi dalam kasus yang diselesaikan melalui mediasi penal, tetapi lebih dominan yaitu adalah delik formil.

Kedua, perkara yang terjadi masuk menurut kategori delik aduan atau tidak. Delik aduan proses penuntutan pelakunya dilakukan oleh orang yang dirugikan dalam hal ini korban. Ketiga, mediasi penal dilakukan apabila antara pihak yang berperkara, baik korban dan pelaku berkaitan erat, dapat dijelaskan bahwa perkara hanya terjadi antara pelaku dan korban dan tidak merugikan pihak lain di luar itu. Kasus pidana yang dilakukan hanya terbatas pada individu, tidak berdampak pada

25 Pinangkaan, N. Op.Cit., hal. 186. 
ketenteraman dan ketertiban suatu wilayah. Kasus seperti ini bisanya disebut sebagai perkara "quasi perdata-pidana", sebab terkadang dalam kasus yang hanya mellibatkan korban individu dan pelaku terdapat unsur perdata dalam menyelesaikan perkaranya. Keempat, kesepakatan harus menjadi dasar yang kuat dalam menyelesaikan kasus pidana dengan mediasi penal, pelaku harus bertanggung jawab atas hak-hak yang diambil dari korban, dalam hal ini perlu adanya kesepakatan yang dianggap tidak merugikan korban, dan pelaku bersedia untuk memberikan kompensasinya. Kelima, adanya mediator (baik polisi, advokat atau pihak ketiga) yang didasarkan pada kesepakatan pelaku dan korban.

Keenam, pelaku dalam melakukan tindakan pidananya tidak memberikan dampak yang besar, sehingga bentuk dari kasus pidana yang dilakukan tidak melanggar norma-norma yang dilindungi oleh masyarakat di suatu wilayah tertentu. Pidana yang tidak termasuk bisa diselesaikan oleh mediasi penal yaitu pembunuhan, perkosaan, makar, penganiayaan yang menimbulkan luka berat dan sebagainya. Akibat dari tindak pidana pelaku hanya bersifat pribadi korban, atau masih dalam lingkup keluarga, sebagai contoh yaitu penipuan, pencemaran nama baik, penggelapan, fitnah, penganiayaan kategori ringan, sehingga hal-hal seperti ini tidak berdampak luas di masyarakat, selain itu sebab yang ditimbulkan dari pelaku memungkinkan untuk dilakukan ganti rugi kepada korban baik materiil dan imaterial. ${ }^{26}$

Agus Raharjo memaparkan beberapa perkara pidana yang dapat menggunakan jalur non litigasi yaitu perkara pidana terkait dengan pencemaran nama baik atau penghinaan (Pasal 310 KUHP), penganiayaan ringan (Pasal 351 KUHP dan Pasal 352 ayat $1 \mathrm{KUHP}$ ), terkait dengan fitnah (Pasal $311 \mathrm{KUHP}$ ), penggelapan (Pasal 372 KUHP), penipuan (Pasal $378 \mathrm{KUHP}$ ), dan tindak pidana karena kelaparan sehingga dapat berdampak pada matinya seseoran (Pasal 359 KUHP). Selain itu mediasi penal juga berlaku di lingkup keluarga, dimana contoh kasusnya adalah perizinaan yang diatur dalam Pasal 285 KUHP, melarikan gadi di bahwah umur (Pasal 332 KUHP), dan pencurian oleh anggota keluarga (Pasal 367 ayat 2 KUHP). ${ }^{27}$

Berdasarkan paparan di atas menunjukkan bahwa mediasi penal dapat dilakukan pada perkara-perkara yang sesuai dengan enam prinsip. Terkadang keputusan yang diambil baik oleh kepolisian, kejaksaan maupun pengadilan hanya memberikan keadilan birokratis yang menerapkan Undang-undang saja, bukan keadilan substansial. Melalui mediasi penal dengan menerapkan enam prinsip di atas, perkara apa pun yang masuk dalam kategori enam prinsip di atas dapat dilakukan dengan jalur non litigasi atau mediasi penal. Melalui mediasi penal asas peradilan yang cepat, sederhana dan biaya ringan dapat tercapai dan tentunya dengan mempertimbangkan keadilan bagi pelaku dan korban. ${ }^{28}$

${ }^{26}$ Raharjo, A. (2008). Mediasi Sebagai Basis dalam Penyelesaian Perkara Pidana. Mimbar Hukum, 20 (1), 99100.

27 Ibid.

${ }^{28} \mathrm{Ibid}$ 
Penerapan mediasi penal dapat menjadi alternatif penyelesaian suatu perkara, dengan tetap mementingkan aspek keadilan. Mediasi penal juga menjadi dalam kasus tindak pidana juga mempercepat proses peradilan antar pihak, sehingga tidak perlu masuk dalam ranah pengadilan. Namun, tidak semua perkara dapat diselesaikan dengan mediasi penal.

\section{Kesimpulan}

Penggunaan mediasi penal sebagai solusi atas penyelesaian permasalahan pidana setidaknya memberikan keringanan pada sistem hukum pidana yang berlaku. Dalam beberapa kasus mediasi penal memberikan "win-win solution", dimana mengurangi keinginan balas dendam korban, mengembalikan hubungan baik korban dengan pelaku, dan tidak pelaku bertanggung jawab atas hak-hak korban. Dasar hukum yang mengatur terkait eksistensi mediasi penal saat ini di Indonesia belum terlalu kuat, tetapi adanya Surat Kapolri No. Pol: B/3022/XII/2009/SDEOPS tanggal 14 Desember 2009 tentang Penanganan Kasus Melalui Alternative Dispute Resolution (ADR) menjadi momentum mediasi penal di Indonesia. Mediasi penal yang sebelumnya lebih eksis dalam perkara perdata namun jika dikaji lagi dapat diterapkan juga dalam beberapa kasus pidana, khususnya dalam pidana Anak. Pada pidana anak pendekatan keadilan restoratif lebih dikedepankan sehingga menghasilkan pemulihan dari perkara pidana yang terjadi. Selain pada pidana anak, penyelesaian melalui mediasi penal juga relevan untuk menghasilkan keadilan restoratif. Melalui mediasi penal, proses penyelesaian perkara tidak hanya berfokus pada mengadili dan menghukum pelaku, tetapi mencari jalan tengah agar dapat memulihkan kondisi korban kejahatan. Hal ini menunjukkan bahwa mediasi penal relevan sebagai upaya untuk mewujudkan keadilan restoratif.

\section{Daftar Pustaka}

Abildanwa, T. (2016). "Mediasi Penal Sebagai Upaya Dalam Rangka Pembaharuan Hukum Pidana di Indonesia Berbasis Nilai-Nilai Keseimbangan". Jurnal Pembaharuan Hukum, 3(1), 138 - 148.

Angrayni, L. (2016). Kebijakan Mediasi Penal dalam Penyelesaian Perkara Tindak Pidana Ringan Perspektif Restorative Justice. Jurnal Hukum Respublica, 16(1), 88102.

Arief, B. N. (2016). Bunga Rampai Kebijakan Hukum Pidana, Jakarta: Prena Media Group.

Berlian, S., Andrisman, T., dan Negara, D. Q. (2019). Mediasi Penal Melalui Lembaga Adat dalam Penyelesaian Kasus Perzinaan, Jurnal Law Reform, 2(2), 19-30.

Briliantari, N. P. M. A. dan Darmadi, A. A. N. O. Y. (2019). Mediasi Penal sebagai Alternatif Penyelesaian Perkara pada Tindak Pidana Body Shaming. E-Journal Imu Hukum Kertha Wicara, 8(8), 1-15. 
Eryke, H. dan Herlambang. (2020). Mediasi Penal Bagi Anak Berkonflik dengan Hukum. University of Bengkulu Law Journal, 5(1), 47-61.

Faisal. (2011). Mediasi Penal Sebagai Alternatif Penyelesaian Perkara Pidana di Luar Pengadilan. Pranata Hukum, 6(1), 81 - 90.

Hariyanto, D. R. S. dan Yogantara, P. (2019). Mediasi Penal dalam Ius Constitutum dan Ius Contituendum di Indonesia. Jurnal Kertha Wicaksana, 13(1), 26-37.

Kamaruddin, dkk. (2013). Model Penyelesaian Konflik di Lembaga Adat. Walisongo, 21(1), 39-70.

Mahendra, A. P. (2020). Mediasi Penal pada Tahap Penyidikan Berlandaskan Keadilan Restoratif. Jurist-Diction, 3(4), 1153-1178.

Mulyadi, L. (2013). Mediasi Penal Dalam Sistem Peradilan Pidana Indonesia: Pengkajian Asas, Norma, Teori dan Praktik". Yustisia, 2(1), 1 - 14.

Pinangkaan, N. (2017). Penerapan Mediasi Penal Dalam Penanganan Tidak Pidana Dalam Pendekatan Keadilan Restoratif Di Kota Manado. Lex Et Societatis, 5(8), $175-188$.

Purnomo, B. S. H. (2018). Kedudukan Mediasi Penal dalam Sistem Peradilan di Indonesia. Jurnal Ilmiah Ilmu Sosial, 4(2), 187-199.

Prihatini, L. (2015). Perspektif Mediasi Penal dan Penerapannya dalam Perkara Pidana. Pakuan Law Review, 1(1), 1-46.

Projodikoro, W. (2003). Asas-Asas Hukum Pidana di Indonesia, Jakarta: Refika Aditama.

Rado, R. H., Arief, B. N., dan Soponyono, E. (2016). Kebijakan Mediasi Penal terhadap Penyelesaian Konflik Sara di Kepulauan Kei dalam Upaya Pembaharuan Hukum Pidana nasional. Jurnal Law Reform, 12(2), 266-276.

Raharjo, A. (2008). Mediasi Sebagai Basis dalam Penyelesaian Perkara Pidana. Mimbar Hukum, 20 (1), 1-191.

Reyner. (2018). Alternatif Mediasi Penal Dalam Sistem Peradilan Pidana di Indonesia". Jurnal Hukum Adigama, 1 - 26.

Salman, H. R. Otje. (2007). Kesadaran Hukum Masyarakat Terhadap hukum Waris, Bandung: PT Alumni.

Sholehuddin, M. (2003). Sistem Sanksi dalam Hukum Pidana, Ide Dasar Double Track System dan Implementasinya, Jakarta: PT Rajagrafindo.

Soekanto, S. (2007). Faktor-Faktor yang Mempengaruhi Penegakan Hukum, Jakarta: Raja Grafindo.

Wijaya, S. A. (2014). Prinsip Mediasi Penal dalam Tindak Pidana KDRT Principle Medaiation of Domestik Violence AS Criminal Act.Jurnal IUS, 11(6), 516-525.

Zilfatun, N. (2003). Sosiologi Hukum, Yogyakarta: Teras.

Zulfa, E. A. (2010). Gugurnya Hak Menuntut Dasar Penghapus, Peringan dan Pemberat Pidana. Jakarta: Raja Grafindo Persada. 